\title{
アカゲザルの腎糸球体血管構築 鋳型走査電子顕微鏡法による観察
}

\author{
岡山大学医学部解剖学第二講座 (主任：村上宅郎教授)
}

畦平孫三郎

（昭和56年 8 月 6 日受稿）

\begin{abstract}
Key words: アカゲザル (rhesus monkey)
腎系球体 (kidney glomerulus)

血管構築 (vascular architecture)

鋳型 (corrosion cast)

走查電顕観察 (scanning electron microscopy)
\end{abstract}

\begin{abstract}
緒
言

腎糸球体が微小血管の密な集塊であることは Malpighi 以来一般に認められている11,2). 腎系 球体の血管構築は従来墨汁注入連続切片あるいは ラテックス樹脂注入鋳型標本など光学顕微鏡的 方法で調べられてきた。しかしながら，標本作 成上の問題や光学顕微鏡の低い解像力, 浅い焦 点深度など技術的制約により, 堅系球体血管構 策の細部とくに系球体内の毛細血管配列につい て多くの問題が残されている。

Vimtrup ${ }^{3) や ~ W i l m e r) ~}{ }^{4}$ 等は主としてイヌなど の動物試料を連続切断法で調へ，腎系球体は相 互に吻合のない独立した数本の毛細血管ループ から成るとした．このループ説は現在まで代表 的な系球体血管分布様式のモデルとして多くの 教科書1),2)に採用されてきた。

Johnston ${ }^{5)}$ はヒトの絿体を連続切片再構築法 て調へ，系球体は独立したループ血管の集合では なく，相互に吻合し合った血管群すなわち毛細 血管網から成るとした。この血管網説は長い間 無視されたが，近年 Hall6)がラテックス注入ラ ット鋳型標本でまた Boyer ${ }^{7)}$, Elias $^{8)}$, Lewis $^{9)}$ がヒト,イヌ, ウサギ, モルモット，ヒツジ試 料の連続切片再構築法で Johnston ${ }^{5}$ のモデルを 支持する結果を得た，特に Hall'b) は系球体毛細 血管網の小葉構造（分葉化）をしめすとともに， 各小葉はそれぞれ独立した形態的機能的血液
\end{abstract}

循環の単位であると述へた。しかしながら、こ れらの研究はいずれも光学顕微鏡によるもので あり, また微小解剖や再構築法等, 技術的問題 もあって，決定的な説得力に欠けていた。

最近，新しく低粘度メタクリレート樹脂によ る微細血管鋳型法が開発され, これと走查電子 顕微鏡観察を組み合せると, 微小循環路すなわ ち微小血管構築について非常に説得力のある所 見が得られることが示された ${ }^{10)}$.この鋳型走査 電子顕微鏡法によって, ラットとヒトの堅系球 体毛細血管叢は分葉化をしめす網を形成するこ とが議論の余地なく明瞭に証明された11),12).

本研究はつカゲザルの堅系球体血管構筑を上 記の鋳型走查電子顕微鏡法で調へ，従来の所見 と比較検討するとともに，系球体内における血 管新生について新知見を追加する。

\section{材料と方 法}

アカゲザル（雄，生後約 1 年）の低粘度メチ ルメタクリレート樹脂胸部大動脈注入によって 腪血管を鋳型した際に得られた腎血管鋳型標本 を使用した (下記参照 $)^{13)}$ 。この標本を実体顕微 鏡下にピンセットで注意深く解剖し，輸入，輸 出動脈を確認しながら45個の督系球体を剖出分 離した。45個の系球体の内訳は腎皮膜下首, 皮 質中部，皮質髄質境界部各15個である。

45個の禾球体のうち15個（皮膜下首, 皮質中 部，皮質鹃質境界部各 5 個）は直ちに（微解剖 


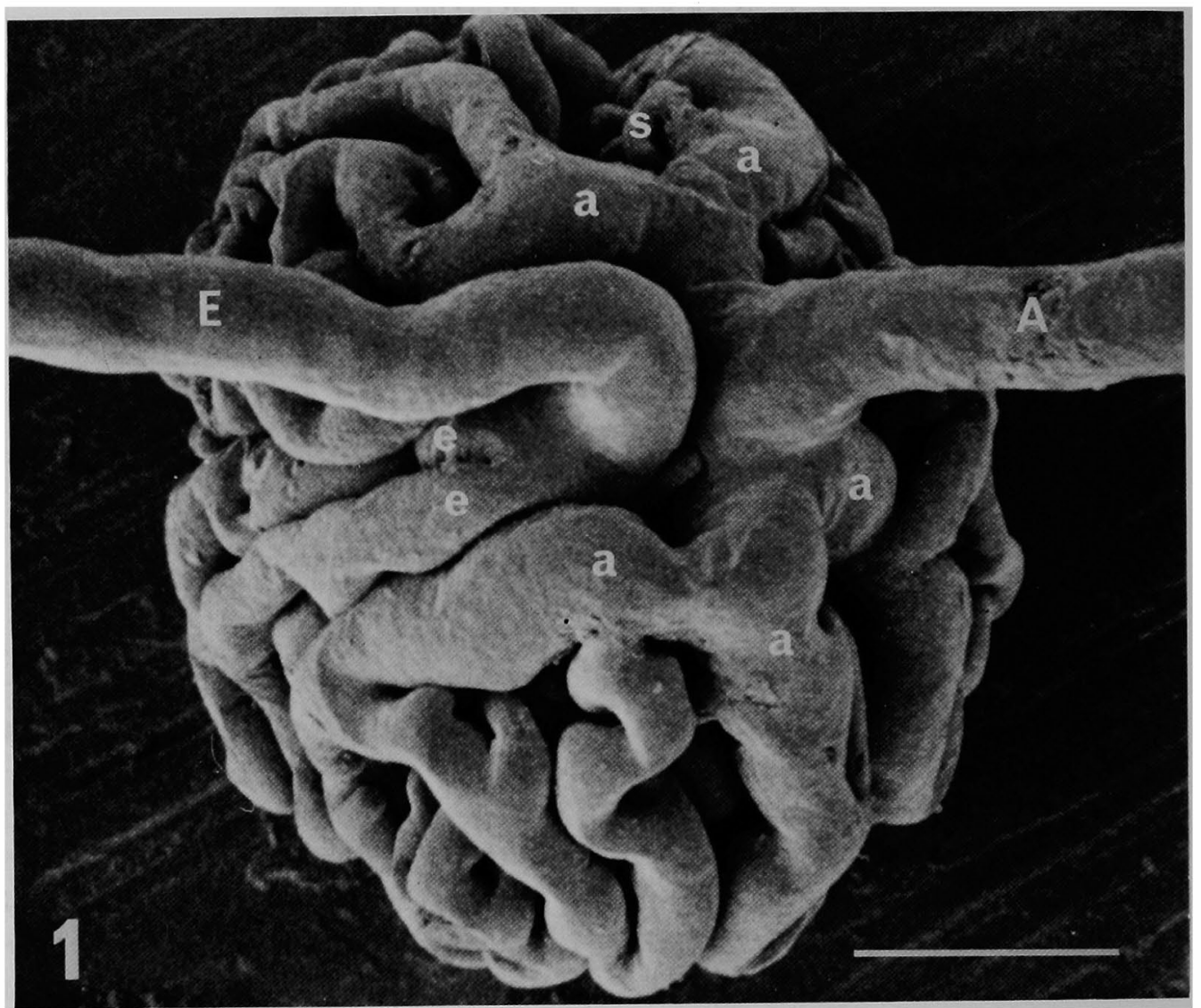

Figure 1. Scanning electron micrograph of a typical subcapsular glomerulus, which was replicated with low viscosity methacrylate resin and isolated from the left kidney of a young male rhesus monkey (about one year old). The glomerulus consists of multiply and freely anastomosing capillary networks. The afferent arteriole (A) divides into the lobular branches or afferent rootlets (a) and supplies the networks of the glomerulus. The efferent vessel (E) receives the efferent rootlets (e) of the networks, and emerges in the vascular pole between the lateral branches of the afferent arteriole. Note that the newly formed vessels (s) with marked thin and slender configurations are directly connected near the vascular pole to a lobular branch. $\mathrm{Bar}=50 \mu \mathrm{m}$.

することなく，下記参照）真空蒸着装置（日本 電子, JEE 4C) 内で金を約 $1000 \AA$ の の厚さに 蒸着し, 加速電圧 $5 \mathrm{kV}$ で走査電子顕微鏡（日本 電子，JSM-U3）下に観察した（Figure 1，2). 残りの30個の系球体は加温エタノール $\left(\right.$ 約 $\left.50^{\circ} \mathrm{C}\right)$ に約 2 時間浸して軟化させ，その後実体顕微鏡 下にピン゙セットで注意深く（輸出・輸入両細動 脈を引張って) 伸展 (Figure 4, 5)あるいは(輸 出・輸入両細動脈側より圧迫または糸球体両外 側部を引張って）展開（Figure 5，6）した ${ }^{11), 14) . ~}$ 30 個のうち伸展した系球体は15個（皮膜下層， 皮質中部，皮質髅質境界部各 5 個），展開した糸
球体は15個（皮膜下層, 皮質中部, 皮質䯣質境 界部各 5 個）である。伸展あるいは展開した糸 球体は冷水に浸して硬化後空気中で乾燥し, 上 記のように金を蒸着して走査電子顕微鏡によっ て観察した。

結果

調べた45個の腎系球体はすべて 1 本の輸入細 動脈と 1 本の輸出細動脈をもち（afferent and efferent arterioles, Figure 1-6), 複数の輸入 あるいは輸出細動脈をもつ異常な系球体はなか った。 


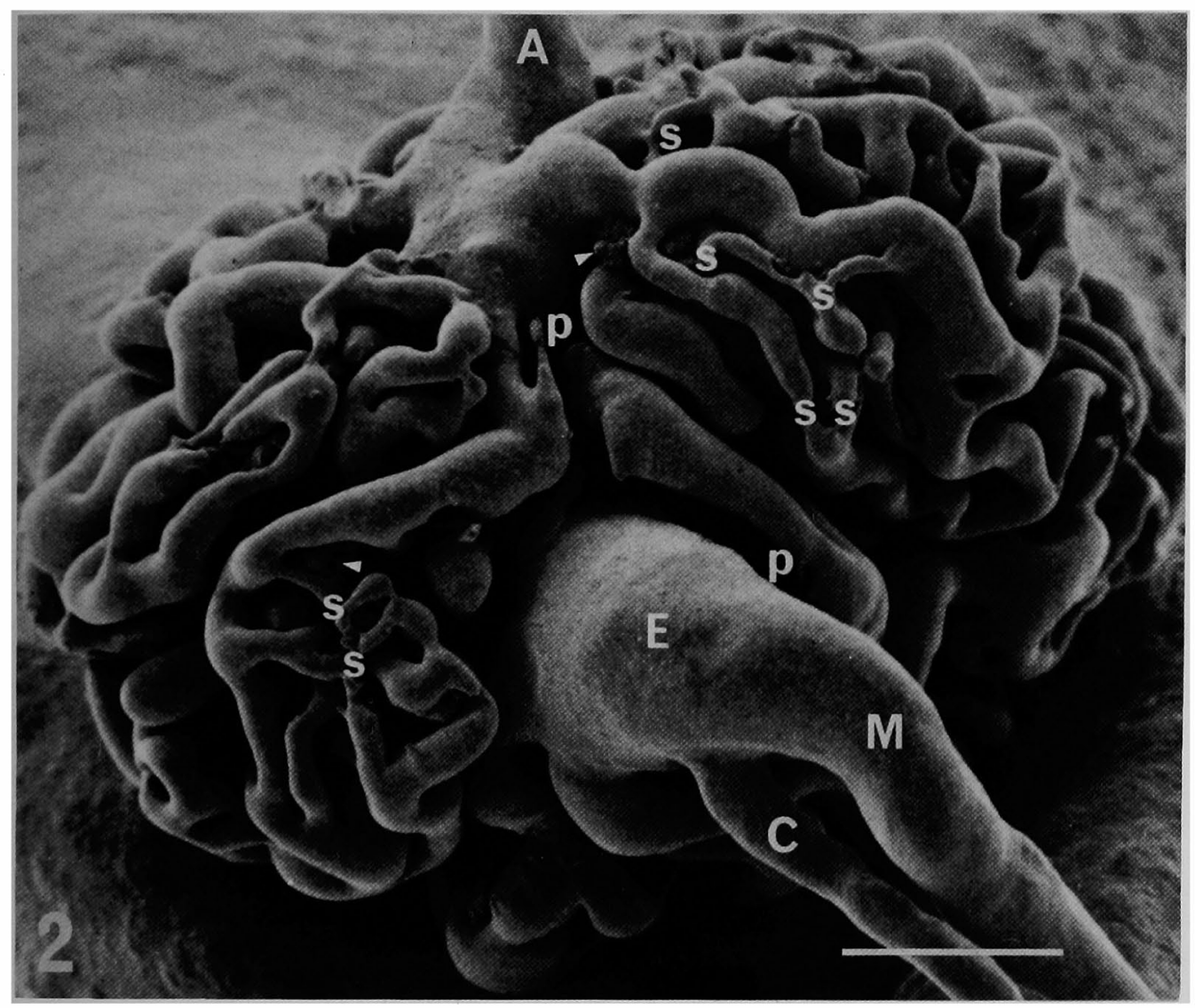

Figure 2. Scanning electron micrograph of a typical cortico-medullary glomerurus of the young rhesus monkey (left) kidney. The cortico-medullary glomerulus is larger in size and richer in capillaries than the subcapsular glomerulus (Figure 1). In the cortico-medullary glomerulus, the afferent vessel $(\mathrm{A})$ is thinner than the efferent arteriole $(\mathrm{E})$ which emits the medullary branch $(\mathrm{M})$ and the cortico-medullary twig $(\mathrm{C})$. The vascular pole, the area between the afferent and efferent vessels, is markedly opened or widened by the invasion of the developed capillary networks. Arrow, leaked resin coagulum; p and s, newly formed capillaries (see text). Bar $=50 \mu \mathrm{m}$.

各系球体は多少の変形はあるとしても, 原則 として球形であった（Figure 1，2）。皮膜下層 からの腎系球体は比較的小さく直径平均約 $150 \mu$

(Figure 1), 皮質中部のものは中間の大きさを 示し直径平均約 $180 \mu$, ，皮質髄質境界部のものは 大きくて直径平均約 $220 \mu$ (Figure 2)であった. また, 輸入細動脈は一般に輸出細動脈より太い が (Figure 1), 皮質髄質境界部の糸球体では常 に輸出細動脈が輸入細動脈より太く鋳型された (Figure 2).

各系球体の輸入細動脈は近傍の小葉間動脈あ るいはその枝から起るが, 皮質能質境界部では
直接弓状動脈から起るものもあった. 皮膜下層 の系球体からの輸出細動脈は皮膜下の, 皮質中 部系球体からの輸出細動脈は同部の腎実質すな わち旁尿細管毛細血管網に移行する. 皮質髄質 境界部の堅系球体輸出細動脈は髄質に下り, 髄 質の旁尿細管毛細血管網をつくる外にその根部 で小枝を派生して皮質髄質境界部の旁尿細管毛 細血管網を養う(Figure 2). 系球体を経ないで 直接旁尿細管毛細血管網に達するいわわ真性 直（達）動脈は発見できなかった。

観察した45個の系球体の内部毛細血管はすべ て良く注入されていた。すなわち, 系球体内各 


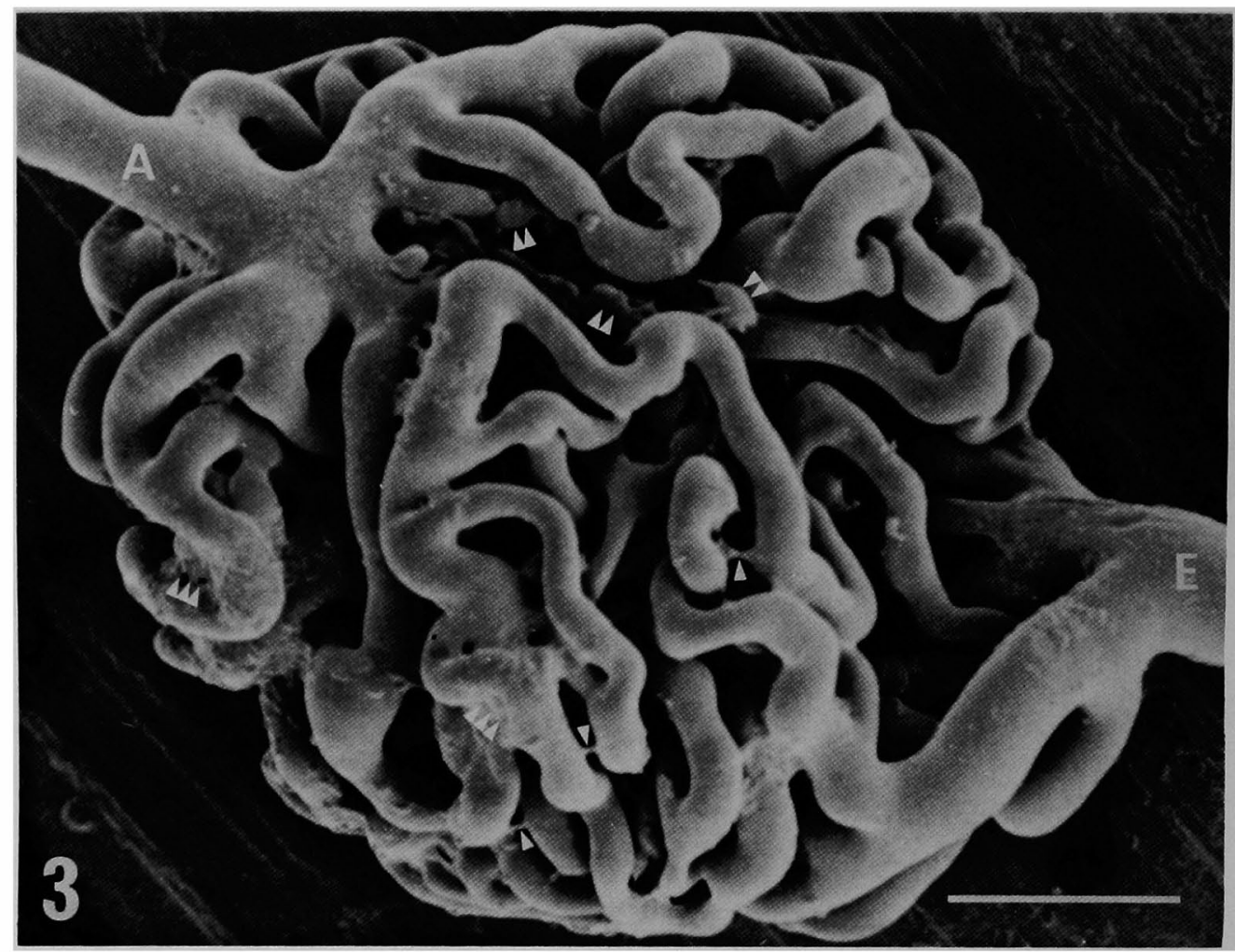

Figure 3. A cortico-merullary glomerulus, which was extended in a warm ethanol bath (a view from the vascular pole). This picture clearly shows that no short-cut communication occurs between the afferent $(A)$ and efferent $(E)$ vessels. Single arrow, thready remnant of macerated tissue; double arrow, leaked resin coagulum; tripple arrow, muddy remnant of macerated tissue. $B a r=50 \mu \mathrm{m}$.

毛細血管は，血管新生をしめすごく細いあるい は盲端で棘状に終るものを除いて(Figure 1, 2)

(下記参照)，十分脹らんだ状態て鋳型されてお $\eta$, これらの血管の不連続性すなわち注入不全 は認められなかった。剖出分離した糸球体の直 接走查電子顕微鏡権察では自然な状態の系球体 血管構築の外観が（Figure 1，2），アルコール 解剖試料では（血管の連絡を損うことなく）内 部の構造すなわち血管配列が観察できた（Figure 3-6). 以下，これらの所見をまとめて述べる。 なお，軽度の樹脂（鋳型郕）の注入漏れや腐 蝕あるいは水洗不足による鋳型の污染が認めら れた。樹脂の注入漏れは小さい付着球 (Figure 3）あるいは不整の凝集塊（Figure 2，3）とし て (下記参照), 軟部組織残存による污染は血管 に張る細い系状の（Figure 3）あるいは不定粘 着物（Figure 3）として認められた。これらの粘
着物や漏出塊はすくなく，またそれぞれの特徵 から血管々明瞭に区別でき，本研究の主眼とし た血管連絡観察の障害とはならなかった。

腎系球体血管は分枝吻合を繰り返して毛細血 管網を形成し（Figure 1-6)，この網は分葉化 をしめす(Figure 4，6).すすなわち，腎系球体輸 入細動脈は血管極で $2 \sim 6$ 本の小葉輸入枝 (10bular branches or afferent rootlets, Figure 1, 4）に分枝する.この小葉輸入枝が三次元的に自 由に分枝吻合を繰り返して，ほぼ独立した小葉 毛細血管網（下記参照）をつくる，小葉血管網 はまず尿管極に向かい，尿管極で反転して再び 血管極に向かい，血管極近くで $2 \sim 4$ 本の小葉 輸出枝 (efferent rootlets, Figure 1，4）とな る。そして各小葉の小葉輸出枝が血管極で集合 して腎系球体輸出細動脈となる，典型的な例す なわち皮膜下系球体では，小葉輸出枝の集合は 


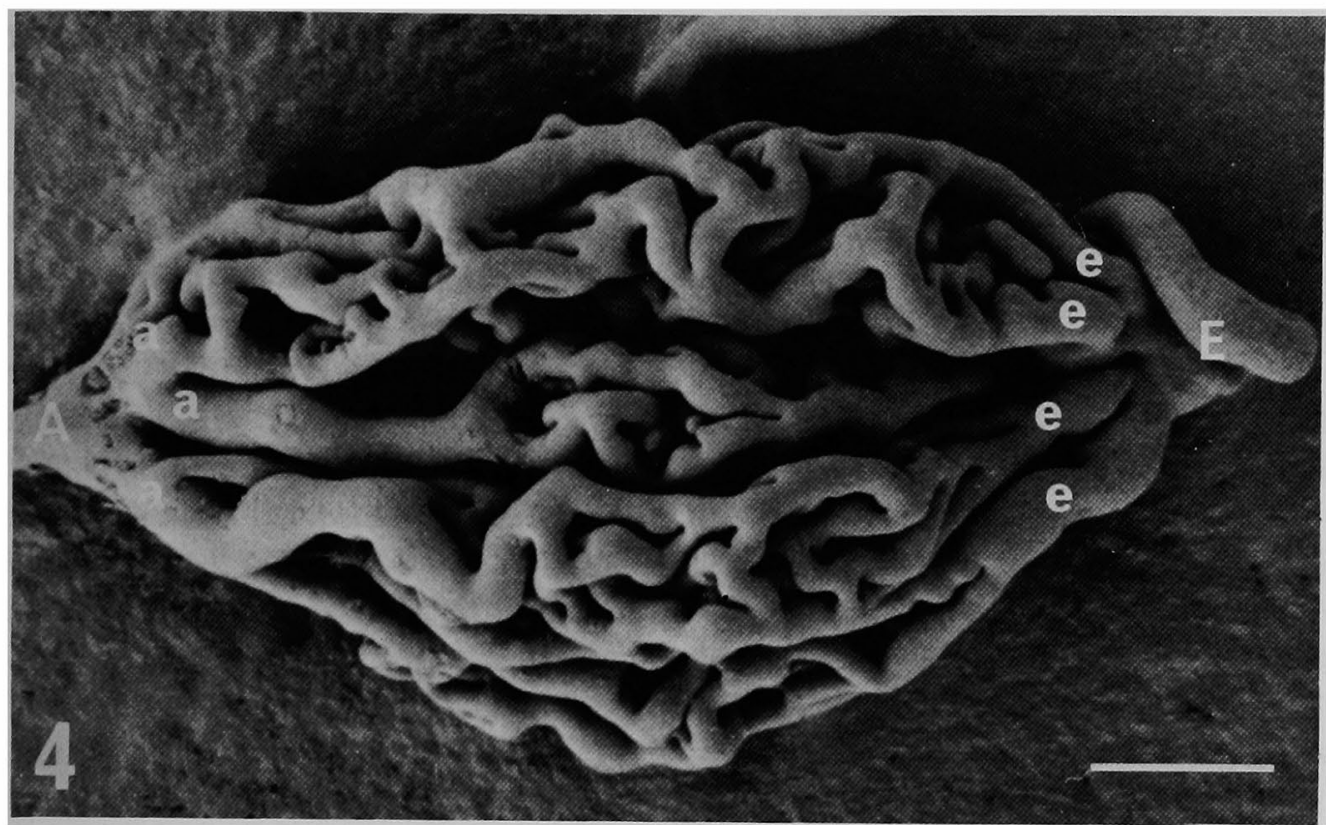

Figure 4. An alcohol-extended mid-cortical glomerulus (a view from the urinary pole). The lobular branches (a) of the afferent arteriole (A) divide into the capillary networks which are confluenced into the efferent rootlets (e). This picture confirms that no main pathway occurs within the glomerular capillary networks. Bar $=50 \mu \mathrm{m}$.

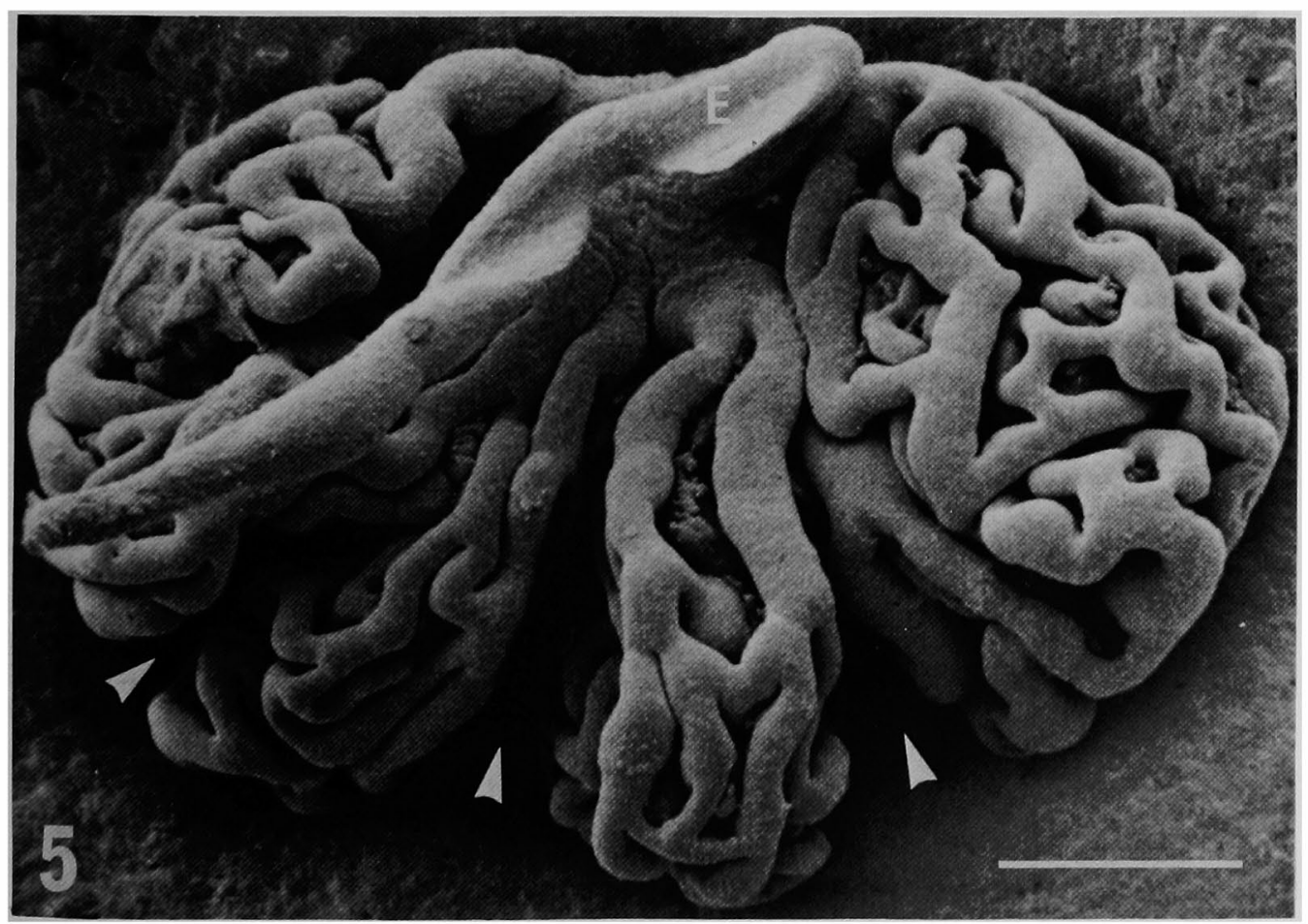

Figure 5. Slightly pressed form of a mid-cortical glomerulus. The glomerulus is divided by three gaps (arrow) into four lobules. This picture exactly proves the lobulations of the glomerular capillary networks. E, efferent vessel. Bar $=50 \mu \mathrm{m}$. 
小葉輸入枝によって両外側から抱きかかえられ， 結果として輸出細動脈は両外側小葉輸入枝の間 から血管極に現われる形態をとる（Figure 1). 糸球体が大きくて血管網のよく発達する皮質䯣 質境界部の系球体 (下記参照) では, 発達した 血管網によって両外側の小葉輸入枝が側方に押 しやられ，必ずしも前述の典型的な形態をとら ない(Figure 2).

糸球体毛細血管網の分葉化（小葉構造）は展 開試料（上記参照）ではじめて明瞭となった (Figure 5，6). 展開した15個の糸球体のうち12 個で全分葉数が判明した，すなわち， 2 分葉化 3 個(すべて皮膜下層)， 3 分葉化 4 個（皮膜下 層 1 , 皮質中部 2 , 皮質䯣質境界部 1 ), 4 分葉 化 3 個（皮質中部 1 , 皮質髄質境界部 2 ) (Figure 5), 5 分葉化 1 個(皮質中部)， 6 分葉化 1 個（皮質髄質境界部）であった。残り 3 個につい ては展開が不十分であったが，1個(皮質下層)
については分葉化が 2 以上，他の 2 個（皮質中 部 1 , 皮質髄質境界部 1 ）では分葉化が 3 以上 と認定された。

各腎系球体毛細血管小葉(lobules, Figure 5) は少数( 1-4 本)の細い毛細血管によって互に 連絡される(Figure 6).この小葉間架橋血管 (bridging capillaries, Figure 6) は血管極近く で，しかも血管小葉の輸出小葉枝近く（すなわ ち，血管小葉の遠位部）で起る。この架橋血管 はアルコール展開試料（上記参照）で明瞭に観 察され，9個の系球体12小葉間で確認できた。 展開した残りの 6 糸球体については展開が十分 でなく，架橋血管について検索できなかった． いずれにしても，観察できた小葉間には常に小 葉間架橋血管が存在した.

系球体の血管網の発達は腎の各層によって異 なる。腎皮質髄質境界部では，系球体が大きく また血管網がよく発達（網を構成する毛細血管

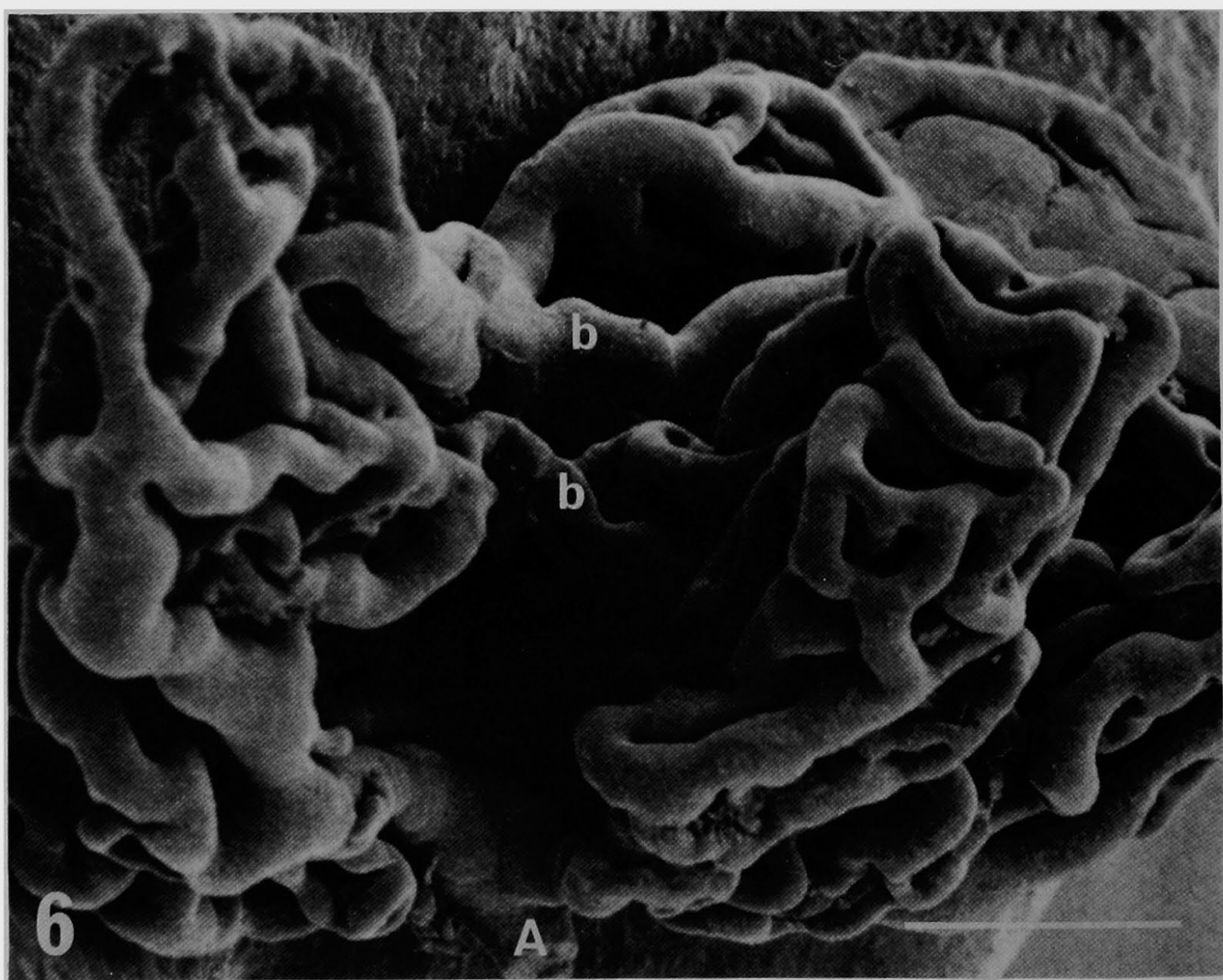

Figure 6. An interlobular area or gap exposed by microdissection in the alcohol bath. The lobules are intercommunicated with each other by a few bridging capillaries (b). A, afferent arteriole. $B a r=50 \mu \mathrm{m}$. 
数が多いということで, 各毛細血管の径が太い ということではない)しており，このために血 管極が開いて輸入, 輸出細動脈間を毛細血管網 の一部が占める(Figure 2). 惄皮膜下の系球体 では，血管網の発達は皮質髄質境界部のものに 比較して極度に劣り, 輸入, 輸出細動脈間に血 管網が侵入することはなかった(Figure 1)。腎 皮質中部では両者が混在したが, 皮膜下型の系 球体が多かった。

禾球体輸入細動脈の分枝はすべて小葉輸入枝 になり，小葉輸入枝はすべて系球体小葉毛細血 管に移行する(下記参照).すなおち, 輸入細動 脈あるいは小葉輸入枝から輸出細動脈あるいは 小葉輸出枝 (上記参照) に直接連絡する短絡あ るいは特定の血管は認められなかった。各小葉 毛細血管網中にも短絡や血流の主路となるよう な特定の血管は認められなかった。これらのこ とはアルコール伸展した系球体（上記参照）で 明瞭に確認できた(Figure 3，4)。

糸球体血管叢の基本構成単位である小葉毛細 血管網の各毛細血管の太さは大小様々であった (Figure 1-6).しかしながら，小葉輸入枝から 分枝した毛細血管が尿管極に向かうに従って次 第に細くなり，また血管極に近づくに従って(小 菓输出枝に集合するにつれて）次第に径を增す という法則性が認められた(Figure 4)。この血 管網中に特に細い毛細血管の集団(s, Figure 1, 2)や鋭利な先端をもって盲端に終る小血管芽 $(p$, Figure 2)が認められた。このような新生血管は 血管網のよく発達した皮質髄質境界部の系球体 に多く認められ，その出現は血管極近く(小葉 血管網中小葉輸入枝に近い部分) に専ら限られ ていた.

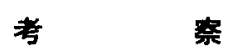

本研究は鋳型の走查電子顕微鏡観察（鋳型走 查電子顕微鏡法) ${ }^{10}$ )は複雑な血管分布連絡様式の 解明に非常に有効な手段であることを確認し， そして低粘度.メタクリレート注入法草は極めて 微細な新生血管の鋳型にも十分使用できること をしめした。

本研究は同時にアカゲザルの腎系球体血管叢 は分葉化をしめす毛細血管網であり，ラットや
ヒトの腎系球体血管構築 ${ }^{111,12)}$ と根本的に同じで あることをしめした。上述したように，Vimtrup 等3),4 は腎糸球体は輸入・輸出細動脈間に張 る数本の独立したループ状の毛細血管から成る と考之た。 そして, Trabucco と Marquez ${ }^{15)}$ 等 は墨汁および樹脂注入標本の光学顕微鏡観察に よって, 系球体が一連の輸入・輸出細動脈から 多数の㐮状にふくらむ房状の小管から成るとし た。しかしながら，古くは Johnston 等の連続 切片光顕観察 ${ }^{51-9)}$ や本研究を含む最近の鋳型走 查電子顕微鏡法111,12)で明らかにされたように, 腎系球体血管叢は輸入・輸出細動脈間に張る毛 細血管網であって，決して吻合のないループで もなく又糞状の房でもない，恐らく Trabucco と Marquez ${ }^{15)}$, Vimtrup ${ }^{3)}$ 等の誤謬は主として 高粘度注入郕や不良連続切片など標本作製技術 の不完全さから生じたものと考えられる。

Kajimierczak ${ }^{16)}$ は出生直後のラットの幼若な 腎系球体を本研究と同じ鋳型走查電子顕微鏡法 で調へ，系球体の分葉化は発育途上極めて早い 時期にすでに認められると述へている。このこ とは本研究で確認した分葉構造は系球体血管構 筑上基本的要素であることを強く示焧している．

各小葉を連絡する架橋血管は Murakami ${ }^{11}$ が ラットではじめて記載し，本研究でも明瞭にそ の存在を確認した. Hall'b)はト, イヌ、ラット のラテックス鋳型押しつぶし標本を光顕で観察 し，小葉間には吻合がなく，従って各小葉は完 全に独立した血液循環単位であると述べた。上 述したように，本研究では小葉間に吻合を認めた， しかしながら，本研究は Hall6)の考之を否定す るものではなく，むしろ彼の説を支持するもの である。すなわち，小葉間の架橋血管は少数で 径も細く，血流の主路とは成り得ない，従って， 各小葉は血液循環の一単位として認め得るもの である、Johnston ${ }^{5)} と$ Boyer ${ }^{71}$ は七卜試料を光顕 による連続切片再構筑法で調へ，ヒトでは腎糸 球体血管叢は分葉化を示さないとした。しかし， 最近の鋳型走查電子顕微鏡法による研究では七 トでも分葉化が明瞭であることが確認されてい $3^{12)}$.

本研究はさらに腎系球体内における血管新生 をはじめて立体的に把握した。すなわち，上述 
係三 郎

したように，血管新生芽は鋳型上血管の「トゲ」 として観察され，開通直後の新生血管は非常に 細い吻合枝として通常の毛細血管間に架橋連絡

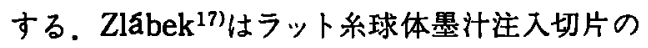
光顕観察で糸球体内に細い毛細血管と太い毛細 血管を区別した，彼はこの二種の血管のうち， 太い毛細血管を血球成分が主として流れ，細い 毛細血管を血球を除いた液体成分が主として通

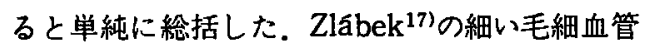
が本研究で述へた新生開通血管に相当する.

新生血管は血管極とその周囲に限って認めら れ，血管極が腎糸球体の主な血管供給源と考之 られる. 新生児ラット 14),16) と成体ラット ${ }^{11}$ の鋳 型走查電子顕微鏡法による比較観察で, 腎糸球 体では加龄によってその血管数が增加し系球体 自身も大きくなることは明らかである。すなわ ち，腎系球体では加齢とともに血管が新生され

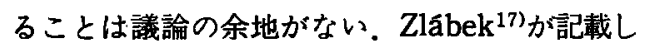
本研究で認めたごく細い新生血管はやがて成長 して通常の毛細血管になると思われる。また個 々の糸球体毛細血管の径の不整は正に各血管の 新生時期を反映するものであろう。すなわち， 比較的太い毛細血管は系球体発育初期に, 比較 的細い血管はごく近い時期に開通完成されたも のと考えてよいと思う。

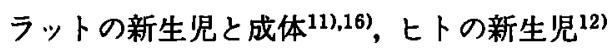
そして本研究の若いサルを通して, 皮質の系球 体は皮質䯣質境界部の系球体より小さく，構成 毛細血管数も少ない。また，腎発生において皮 質髄質境界部の系球体が最初に分化し，皮質特 に皮膜下の糸球体の分化は遅れることが知られ ている。これらのことと上記の加秢による血管 数の增加の事実は, 発生初期加成人に至るま で，皮質と皮質髄質境界部の系球体においては は同じ程度に血管が新生成長していることを示 している，換言すれば，正常腎における糸球体 の大小と構成血管の多璂はそのままその系球体 の分化時期の早遅を反映していることになる。 系球体内毛細血管路に関連して, Hall6) は七 ト,イヌ、ラットの系球体小葉中に特に太い毛 細血管が存在し，この血管が輸入細動脈と輸出 細動脈間の側副路となっていると述へた。また， Ljungquist ${ }^{18)}$ Casellas と Mimran ${ }^{19}$ /は墨汁や
ラテックス注入標本の光顕観察で, ヒト，ウ サギ, ラットの腎系球体輸入細動脈と輸出細動 脈を直接結ぶ短路を報告している。しかしなが ら, 本研究を含めた最近の信頼すべき低粘度注 入剤による鋳型走查電子顕微鏡観察 ${ }^{11), 12), 20), 21,22}$ や樹脂包埋連続切片の電顕再構築法 ${ }^{23}$ による上 ト，サル，ラットの調查では，小葉内はもちろ んのこと輸入・輸出細動脈間に, 如何なる短路 や側副路あるいは特定主要血管路も確認されて いない。ただ, Spinelli等 20)が鋳型走查電子顕微 鏡法で老㱓ラットの小葉辺緑部を走る太い血管 を認め，これを主要血流路と述べている。しか しながら，彼等の研究は系球体を外部から観察 したのみで，微解剖を駆使した内部観察を总つ ておク，必ずしも信用できない。おそらく内部 にも太い血管（すなわち発生的に旧い血管，上 記参照）が存在するはずであり，辺縁のものだ けを観察特記することは微小循環研究上甚だ妥 当性を欠くものである。

鋳型走查電子顕微鏡法によるラットの調查で, 腎系球体は稀に重複輸入年)方るいは重複輸出 ${ }^{14)}$ 細動脈を持つことが知られている，本研究では これらの異常な破格は認められなかった。これ は調查した例数が限られたためである.

本論文では，個々の血管の太さ（径）の数值 はとくに述へてていない。れは低粘度注入郕で は血管が十分に注入される反面, 内腔が過度に 拡大した状態で再現され，必ずしも自然な血管 内腔を描写しないと同時に一般に固定収縮した 試料の光顕あるいは電顕観察で計測される数値 とも对応しないからである．また，生体では堅 系球体においてもすへての毛細血管中を常に血 液が充満して流れているわけではない。すなわ ち，血管とくに毛細血管では血管の太さは何に 基準を置いて求めるかという問題があり，すく なくとも著者は過度に拡張した状態での計測は 生理学的にも形態学的にもあまり意味を持たな いと考える，従って，本論文では血管径につい て太い」「細い」など相对的抽象的表現にとど め，㨂入した写真中に目盛指標をしめして一応 の参考に供した。なお，本稿で述べた「太い」 「細い」は血管の内腔（すなわち，内径）を表 現したもので，血管壁を含むいわゆる外径を示 
すものではない。もちろん，写真でしめされた 鋳型（Figure 1一6）は血管内腔を再現したもの である。

本研究で用いた低粘度注入剂は縮合し，硬化 後80 90\%容積となる。従って, 注入剂が血管 内で長さに変化なく硬化したとすれば，鋳型は 注入された血管の約89 94\%径（太さ）を示す こととなる。しかし，実際には硬化時長さも同 様に収縮すると考えるのが妥当であり，この場 合計算上 (球として均一に収縮するものとして) 鋳型は注入血管の約 $93 \sim 97 \%$ 径（太さ）を再現 することになる。そとして，走查電子顕微鏡の機 械的誤差とその操作による人為的誤差が最少士 10\%加わる。従って，最終的に写真に記録され る各血管鋳型は注入された血管の約 $84 〜 107 \%$ の径（太さ）を示すことになる。

本研究で用いた低粘度メタクリレート注入剤 は約 10 centipoiseの粘度をもち, 胸部大動脈よ り約200mm水銀柱圧で注入された。述したよう に，軽度ではあるが注入用の漏出が認められた。 このことは本研究で観察した鋳型標本は血管が 破れる寸前まで最大限に搪張した血管内腔を再 現していることを示している。なお，注入郕の 漏出による樹脂の不整凝集塊（Figure 2，3）は
血管壁内の，そして球状塊（Figure 3）は血管 壁外への漏出として理解される。

\section{結铻}

アカゲザル腎系球体血管並を低粘度メタクリ レート樹脂で鋳型し，走查電子顕微鏡で観察した。 腎系球体血管叢は自由に吻合を繰り返す毛細 血管網からなり，この網は分葉化をしめした。 各分葉は少数の架橋毛細血管で互に交通してい た、しかしながら，架橋血管は細く，各分葉は 微小循環上独立した単位として認め得るもので あった。

非常に細い毛細血管がときどき系球体の血管 極とその周囲に観察された。これらの微細血管 は系球体における血管新生をしめすものである。

糸球体輸入・輸出細動脈間そして系球体毛細 血管網中には，如何なる血管の短絡や主路も認 められなかった。

部辞

本研究を進めるにあたって，終始村上宅郎教授の 指導と援助を得た。 また, 赤羽学教授（岡山大学文 学部）には論文の校閲をしていただいた。而博士に 厚く御礼申し上げる.

\section{文献}

1. Bargmann, W.: Histologische und Mikroskopische Anatomie des Menschen 6., Auflage, Georg Thieme Verlag, Stuttgart, pp. 510-536, 1967.

2. Bloom, W. and Fawcett, D.W.: $A$ Textbook of Histology 10th ed., W.B. Saunders Co., Philadelphia-LondonToronto, pp. 766-797, 1976.

3. Vimtrup, B.J.: On the number, shape, structure, and surface area of the glomeruli in the kidneys of man and mammals. Am. J. Anat. 41, 123-151, 1928.

4. Wilmer, H.A.: The arrangement of the capillary tuft of the human glomerulus. Anat. Rec. $80,507-$ $518,1941$.

5. Johnston, W.B.: A reconstruction of a glomerulus of the human kidney. Anat. Anz. 16, 260-266, 1899.

6. Hall, B.V.: Further studies of the normal structure of the renal glomerulus. In Proceedings of 6 th Ann. Conf. Nephrotic Syndrome, Nat. Nephrosis Found., New York, pp. 1-39, 1955.

7. Boyer, C.C.: The vascular pattern of the renal glomerulus as revealed by plastic reconstruction from serial sections. Anat. Rec. 125, 433-441, 1956.

8. Elias, H.A.: De structura glomeruli renalis. Anat. Anz. 104, 26-36, 1957.

9. Lewis, O.J.: The vascular arrangement of the mammalian renal glomerulus as revealed by a study of 
. its development. J. Anat. 92, 433-440, 1958.

10. Murakami, T.: Application of the scanning electron microscope to the study of the fine distribution of the blood vessels. Arch. Histol. Jpn. 32, 445-454, 1971.

11. Murakami, T.: Vascular arrangement of the rat renal glomerulus. A scanning electron microscope study of corrosion casts. Arch. Histol. Jpm. 34, 87-107, 1972.

12. Murakami, T.: Methyl methacrylate injection replica method. In Principles and Techniques of Scanning Electron Microscopy Vol. 6, ed. A. M. Hayat, Van Nostrand Reinhold Co., New York-CincinnatiAtlanta-Dallas-San Francisco, pp. 159-169, 1977.

13. Fujita, T. and Murakami, T.: Microcirculation of monkey pancreas with special reference to the insulo-acinar portal system. A scanning electron microscope study of vascular casts. Arch. Histol. Jpm. 35, 255-263, 1973.

14. Murakami, T., Miyoshi, M. and Fujita, T.: Glomerular vessels of the rat kidney with special reference to double efferent arterioles. A scanning electron microscope study of corrosion casts. Arch. Histol. Jpn. 33, 179-198, 1971.

15. Trabucco, A. and Marquez, F.: Structure of glomerular tuft. J. Urol. 67, 235-255, 1952.

16. Kajimierczak, J.: A study by scanning (SEM) and transmission (TEM) electron microscopy of the glomerular capillaries in developing rat kidney. Cell Tiss. Res. 212, 241-255, 1980.

17. Zlábek, K.: Über dünne intercapillare Anastomosen im Nierenglomerulus der Ratt. Acta Anat. 85, 177-189, 1973.

18. Ljungquist, A.: Ultrastructural demonstration of a connection between afferent and efferent juxtamedullary glomerular arterioles. Kidney Int. 8, 239-244, 1975.

19. Casellas, D. and Mimran, A.: Glomerular pathways in intrarenal microvasculature of aged rats. Am. J. Anat. 156, 293-298, 1979.

20. Spinelli, F.R., Wirz, H., Brücher, C.H. and Pehling, G.: Non existence of shunts between afferent and efferent arterioles of juxtamedullary glomeruli in dog and rat kidneys. Nephron 9, 123-128, 1972.

21. Spinelli, F.R.: Structures and development of the renal glomerulus as revealed by scanning electron microscopy. In International Review of Cytology 39, ed. G. H. Bourne and J.F. Danielli, Academic Press, New York-San Francisco-London, pp. 345-381, 1974.

22. Anderson, B.G. and Anderson, W.D.: Renal vasculature of trout demonstrated by scanning electron microscopy, compared with canine glomerular vessels. Am. J. Anat. 145, 443-458, 1976.

23. Yang, G.C.H. and Morrison, A.B.: Three large dissectable rat glomerular models reconstructed from wide-field electron micrographs. Anat. Rec. 196, 431-440, 1980.

24. Murakami, T.: Double afferent arteriole of the rat renal glomerulus as studied by the injection replica scanning electron microscope method. Arch. Histol. Jpn. 39, 327-332, 1976. 
Blood vascular architecture of the rhesus monkey kidney Glomerulus.

A scanning electron microscope study of corrosion casts

$$
\text { Magosaburo UNEHIRA }
$$

Department of Anatomy, Okayama University Medical School, Okayama, Japan

(Director: Prof. T. Murakami)

Blood vascular beds of the rhesus monkey kidney glomerulus were replicated with low viscosity methacrylate resin and observed in a scanning electron microscope.

The glomerular blood vaseular beds consisted of freely and multiply anastomosing capillary networks, which showed lobulations. The lobules intercommunicated with each other by a few bridging capillaries. The lobules, however, could be recognized as fairly independent units in the glomerular microcirculation as the bridging vessels were small in size.

Very faint capillaries were sometimes observed in and near the vascular pole of the glomerulus. These faint vessels represented new formations of the glomerular capillaries.

Neither short-cut communication nor main pathways were noted between the glomerular afferent and efferent vessels nor within the glomerular capillary networks. 